\title{
The Governance Dilemma and Direction of Rural Collective Economic Organization Legal Person
}

\author{
Zhenjun Tang \\ Law School, Anhui University of Finance and Economics, Bengbu, China \\ Email: tangzhenjun20@163.com
}

How to cite this paper: Tang, Z. J. (2020). The Governance Dilemma and Direction of Rural Collective Economic Organization Legal Person. Open Journal of Social Sciences, 8, 426-439.

https://doi.org/10.4236/jss.2020.812034

Received: November 25, 2020

Accepted: December 27, 2020

Published: December 30, 2020

Copyright (๑) 2020 by author(s) and Scientific Research Publishing Inc. This work is licensed under the Creative Commons Attribution International License (CC BY 4.0).

http://creativecommons.org/licenses/by/4.0/

\section{(c) (i) Open Access}

\begin{abstract}
The promulgation of the General Provisions of the Civil Law of the People's Republic of China officially established the status of rural collective economic organizations as special legal persons, and the Civil Code of the People's Republic of China adopted on May 28, 2020 also affirmed the status of rural collective economic organizations as legal persons. At present, there is a lack of national-level legislation on the specific governance content of rural collective economic organizations. Most local regulations directly stipulate the governance issues of rural collective economic organizations, resulting in formalism in the content of regulations and inconsistent governance structure of rural collective economic organizations in the process of governance. Improve and "separate politics from economics" difficult issues. In this regard, it is necessary to combine the particularity of collective economic organizations, pay attention to the procedural matters and content of the formulation of the charter, establish a "three-tier" governance structure model for internal and external supervision, and achieve "politics" by separating the functions and personnel of rural collective economic organizations and village committees. After separation, the direction of governance will be clarified, and the governance problems of rural collective economic organizations as legal persons will be solved.
\end{abstract}

\section{Keywords}

Rural Collective Economic Organization, Special Legal Person, Separation of Government and Economy, Governance

\section{Introduction}

At present, the exploration of local legislation on the governance of rural collec- 
tive economic organizations has gone ahead of the national legislation. Many areas, represented by Heilongjiang Province and Guangdong Province, have explored the regulations, governance structure and asset management of rural collective economic organizations through the formulation of "Measures for the Organization and Management of Rural Collective Economic Organizations" and "Regulations on the Management of Rural Collective Assets". Although the General Provisions of the Civil Law of the People's Republic of China at the level of national legislation stipulates that rural collective economic organizations are established according to law and have the status of special legal persons, it lacks detailed provisions on the specific content of rural collective economic organizations. However, local normative documents are limited by the lower level of legislation, and different regions have different provisions on the governance content of rural collective economic organizations, so a high-level legislation is still needed to carry out special regulations on the governance content of rural collective economic organizations. Obviously, the state has also recognized this problem. The State clearly recognizes this problem, and the "No. 1 Central Document" from 2017 to 2019 proposes a macro-strategy for the development of rural collective economic organizations, which indicates that the development of rural collective economic organizations is an inevitable trend and also reflects the importance of studying rural collective economic organizations. Therefore, it is necessary to explore the governance problems of rural collective economic organizations, so as to find specific solutions.

\section{The Special Nature of Legal Person of Rural Collective Economic Organization}

Special legal person is the status symbol of rural collective economic organization. Therefore, the primary goal of constructing the governance content of rural collective economic organization is to clarify its particularity, thus to clarify the difference between rural collective economic organization and other legal persons, and to provide specific direction for the design of the constitution and governance structure of rural collective economic organization. But the current legislation does not make clear the rural collective economic organization legal person's special place, then still needs to explore the rural collective economic organization's special nature, in order to make clear the specific development direction of rural collective economic organization governance.

\subsection{The Uniqueness of the Legal Person Type}

The legislation adopted a new legal person classification method, which stipulated the special legal person for the first time in the legal person type and endowed the rural collective economic organization with the special legal person status. This classification method highlights the parallelism of special legal person, profit-making legal person and non-profit legal person, and also clarifies the special nature of rural collective economic organization as special legal per- 
son in the type of legal person. Up to now, some scholars still advocate abandoning the title of special legal person and tend to classify the rural collective economic organization into the type of profit-seeking legal person (Guo, 2019). This is obviously inconsistent with the General Provisions of the Civil Law of the People's Republic of China. The emergence of special legal persons is to make up for the omission of profit-seeking legal persons and non-profit legal persons. It is precisely because the rural collective economic organizations cannot be classified into either profit-seeking legal persons or non-profit legal persons that special legal persons emerge at the right moment. Profit-seeking legal person with rural collective economic organizations on the one hand, there exists a significant difference between the two: the purpose of the for-profit legal person is for profit, and the rural collective economic organizations of for-profit isn't the only targets, it still take into account a certain public service function and the function of asset management, prevent the loss of collective assets and revitalize the collective assets and its important function; On the other hand, non-profit legal person and rural collective economic organizations also have a significant difference: non-profit legal person does not have the purpose of making profits. The establishment of non-profit legal person is mainly for public welfare. Its members do not enjoy the distribution of profits, and all the profits will be invested in public welfare undertakings free of charge. Collective economic organizations, on the other hand, have the functions of making profits and providing community public services. For example, each rural collective economic organization designs individual shares while designing collective shares, which not only satisfies the function of providing public services, but also enables the income to be effectively controlled by individuals. Therefore, special legal person is not just a simple name, the rural collective economic organization is different from the other two types of legal person in the type of legal person, we should accurately grasp the special nature of its legal person type.

\subsection{Special Nature of Membership}

The composition of the members of rural collective economic organizations has the characteristics of community. The acquisition of membership is limited to the members of the collective economic organization, and the non-members of the collective economic organization are not allowed to become shareholders, which also determines the prohibition of the transfer of member shares to the outside world. Moreover, there is no problem of inheritance in such membership, and once the identity relationship of collective members is lost, the identity of shareholders will be lost. Identity is an important criterion for evaluation. All normative documents in Zhejiang province take household registration as a necessary factor in defining membership. "Regulations of Village Economic Cooperative Organizations of Zhejiang Province" take household registration and other factors as the basis for membership evaluation, and explicitly prohibit the possibility of anyone other than a member of the collective becoming a share- 
holder.

\subsection{The Special Nature of Voting}

Legal persons have independent subject status and need to go through the voting procedure when making decisions, special legal persons are not excluded. Rural collective economic organizations of a vote also adopt the method of "majority", just a vote at the rural collective economic organization is different from stock company as a legal person and the enterprise as a legal person in accordance with the amount of equity allocation of voting rights, its shareholders to follow is the principle of "one person one vote" exercise their voting rights, Ministry of Agriculture and Rural Affairs of the People's Republic of China printed and distributed to the articles of association of the rural collective economic organizations demonstration (try out) "affirmed the same voting rights allocation". The owners of rural land are not villagers, and the members' shareholder status is not obtained through capital contribution, but based on a specific status. Therefore, the right to vote cannot be allocated according to the amount of land occupied. Exercising the right to vote according to the requirement of "one person, one vote" can better reflect the special and fairness of collective economic organizations.

\subsection{Special Nature of Contributions by Members}

The membership of a member as a shareholder does not presuppose actual capital contribution. The current law of our country has clearly stipulated the operation mode of household contract responsibility system, which is still playing a positive role. With the continuous progress of rural property right reform, there are more alternative forms of rural collective economic organization, such as stock cooperative and cooperative organization. Through the reform of rural property rights, members can enjoy the shareholder status in rural collective economic organizations, but this shareholder status is not obtained through investment, but through membership, with the characteristics of non-payment. Based on the characteristics of the household contract responsibility system, members get the contracting right of collective land free of charge. While ensuring the ownership of rural land does not transfer, the collective members transfer the right of land management at the same time, so that the collective assets can be quantified into shares and distributed to members (Jiao, 2019). The shareholder's contribution is to convert the contracted land contracted by villagers into shares, which is very different from the actual contribution of corporate shareholders.

\section{The Practice Difficult Problem of Rural Collective Economic Organization Legal Person Management}

\subsection{Formalism in the Constitution of Rural Collective Economic Organizations}

The constitution of rural collective economic organization is the key to coordi- 
nate and solve the agriculture-related disputes (Zhao, 2018). Although the law expressly stated the rural collective economic organizations should have the articles of association, but released in December 2016, "the central file no. 1" in the clear requirements after the collective property rights reform of the rural collective economic organization "to perfect the governance mechanisms, formulate articles of association", and Ministry of Agriculture and Rural Affairs of the People's Republic of China in November 2020, issued by the articles of association of the rural collective economic organizations demonstration (try out) is used to guide the rural collective economic organizations formulation of regulations, clearly shows the importance and necessity of the articles of association of sex. "The model Articles of Association of Rural Collective Economic Organizations (Trial)" issued by the Ministry of Agriculture and Rural Affairs of the People's Republic of China reflects some problems in the articles of Association of local rural collective economic organizations. The specific problems are as follows:

First, there is a lack of procedural provisions. Constitution is the criterion that rural collective economy organization is engaged in an activity, it is the key that legal person manages. Although local norms have made corresponding provisions on the subject of the constitution and the amendment procedure, the overall provisions are relatively crude, lacking special chapter provisions on the amendment matters of the constitution, ignoring the provisions of meeting minutes and the principle of publicity. Not only does the constitution of local rural collective economic organizations ignore the procedural provisions of the constitution, amendment and publicity, but even the "Model Constitution of Rural Collective Economic Organizations (Trial)" issued by the Ministry of Agriculture and Rural Affairs of the People's Republic of China also ignores the procedural provisions of the constitution, only stipulating the subject of the constitution and amendment in the organizational structure. The lack of procedural provisions in the articles of association leads to the fact that the amendment of the Articles of Association in reality is often separated from procedural matters, such as meeting minutes lacking the amendment of the Articles of Association and procedural problems such as the number of participants not reaching the standard when the amendment of the Articles of Association is made. Lawsuits arising from this are also common. For example, in case No. 3331 of Zhejiang Hang Minzizhong (2014), the joint-stock economic cooperative failed to hold a meeting of shareholders' representatives and forged the minutes of the third meeting of shareholders' representatives, thus forming a new constitution and finally denying the shareholder status of some villagers. These problems are caused by the lack of meeting minutes and other procedural matters, which obviously violates the amendment procedure of the bylaws and ignores the guiding role of the bylaws.

Second, the constitution lacks specificity. Following the promulgation of the "Model Articles of Association of Rural Collective Economic Organizations" in many provinces and municipalities, the Ministry of Agriculture and Rural Af- 
fairs of the People's Republic of China has also published the "Model Articles of Association of Rural Collective Economic Organizations (Trial)". However, the previous constitutions of local collective economic organizations lacked the guidance of unified model constitutions, resulting in the various contents of the constitutions of local collective economic organizations, ignoring the special nature of rural collective economic organizations. In practice, the constitution of many areas neglects the economic characteristics of rural collective economic organizations and lays too much emphasis on the function of public service. In particular, the high proportion of collective shares in the articles of association of the western backward areas, which use more of the proceeds for public services, is difficult to implement on the individual shareholders, and ignores the economic functions of rural collective economic organizations (Li, 2019). In addition, the constitution does not set the question of the loss of membership, only stipulating the conditions for the acquisition of membership. Qualification is a prerequisite for villagers to enjoy rights and assume responsibilities. It is also an important part of the constitution. Article 11 of the "Model Articles of Association of Rural Joint-stock Economic Cooperatives of Haitian District (for trial implementation)" only specifies the conditions for becoming a shareholder, but ignores the loss of the shareholder's qualification, which makes it easy for the phenomenon of judicial disunity to occur.

\subsection{Imperfect Governance Structure}

The governance structure is the essential organ of a legal person ( $\mathrm{Qu}, 2018)$. Although the General Provisions of the Civil Law of the People's Republic of China have few provisions on rural collective economic organizations, the "general provisions" of the chapter on Legal persons are equally valid for rural collective economic organizations. It is clearly specified in the "General Provisions" of the chapter on Legal Persons that a legal person should have an "organizational structure". A complete governance structure is the guarantee for the normal operation of a legal person, so is a special legal person. This has also been proved in real life. For example, "Regulations of Zhejiang Province on Organization of Village Economic Cooperatives"1, "Regulations of Heilongjiang Province on Rural Collective Economic Organizations" and "Administrative Measures of Daguan District on Rural Collective Economic Organizations"3 have stipulated the governance structure of rural collective economic organizations. Although local governments have made preliminary provisions on the governance structure, there are still some problems:

\footnotetext{
"Regulations of Zhejiang Province on Organization of Village Economic Cooperatives" stipulates that the governance structure of the society consists of a general meeting of members, a management committee and a supervisory committee.

${ }^{2}$ "Regulations of Heilongjiang Province on Rural Collective Economic Organizations" stipulate that the governance structure of the society consists of a general assembly, a board of directors, and a supervisory board.

3“Administrative Measures of Daguan District on Rural Collective Economic Organizations" stipulates that the governance structure of the organization consists of a general assembly, a board of directors, and a supervisory board.
} 
First, the governance structure mode is not unified. Practice varies from place to place on what form of governance structure to take. It can be roughly divided into two forms: the first is modeled on the "three-tier" governance structure that companies build. For example, the Regulations of Heilongjiang Province on Rural Collective Economic Organizations stipulate that the rural collective economic organizations in the administrative region shall adopt the governance structure of the general assembly (the representative assembly of the members), the Board of directors and the Board of supervisors. The Regulations of Zhejiang Provincial Village Economic Cooperatives organization also stipulate the governance structure of the member congress, the social management committee and the social supervision committee. The second form is an original "two-tier" governance structure. The Measures for the Administration of Rural Collective Economic Organizations in Hubei Province stipulates that the organizational structure shall be composed of the member's Congress (the member's representative congress) and the management committee. As for the first form, the governance structures in different regions are constructed according to the authority - the executing agency-the supervision agency, even though the names are different. The construction of the governance structure is relatively complete, which makes clear the source basis of the supervision right. The second form of governance structure is lack of supervision institutions, it is difficult to ensure the mutual checks and balances within the governance structure.

Second, lack of internal and external supervision mechanism. In reality, the problem of insider control is prominent and the intervention of external supervision is lacking. Although many regions have set up governance structures and stipulated the composition of the personnel of governance structures, they have not gotten rid of the closed nature of rural collective economic organizations. Therefore, members outside the collective economic organizations cannot participate in the governance and supervision of the legal person of the collective economic organizations, which easily leads to the emergence of internal minority control problems. Taking the management of collective assets as an example, although corresponding governance structures have been introduced in various regions in practice, many regions do not require hiring professional intermediary institutions for the verification of collective assets, which will lead to the encroachment of collective assets. The members of the supervisory organization are all members of the collective, and there are affinity and blood relationship among the members of the collective, which makes the supervisory organization become a decoration in practice. At this time, the lack of external supervision easily leads to the situation that the decision-making power is controlled by a few hands, which undoubtedly aggravates the operation difficulty of collective economic organizations as legal persons.

\subsection{The Separation of Government and Economy Has Not Yet Been Achieved}

The demise of the people's commune represents the mode of "political and eco- 
nomic integration", which is no longer suitable for the current development. With the dissolution of the people's commune, its economic and political functions will not dissipate. The ideal state is that the economic functions of the people's commune are undertaken by the rural collective economic organization, while the administrative functions of the people's commune are undertaken by the village committee, so as to achieve the mode of "separation of politics and economy". Limited by the regionalism of our country's development, the construction of rural collective economic organizations in many areas is still not independent, and there are a lot of confusion between villagers' autonomous organizations and rural collective economic organizations (Guan, 2019). So far, the separation of government and economy has not been realized, which is shown in practice as follows:

First, conflicts exist between the functions of rural collective economic organizations and villagers' committees. The main conflict between the two functions is that both have administrative functions over collective assets, the law confirms the functions of village committee and village collective economic organization in the management of collective land and endows them with legitimacy in the management of collective assets (Zhang, 2016). Land Contract Law of the People's Republic of China states that both the villagers' committee and the village collective economic organization have the right to grant the collective land, but it does not distinguish the relationship between the two as well as the specific economic and administrative functions. Legislation failed to distinguish between villagers committee and the rural collective economic organizations on the collective asset management of administration and economic functions, is reflected in practice do less than mutual interference between functions, many of the local regulations set forth the collective economic organizations should accept the supervision of the villagers committee, such as "daguan district rural collective economic organization and management method (trial)" is explicitly give the villagers committee for the rural collective economic organizations have supervision power.

Second, there is overlap between the staff of rural collective economic organizations and villagers' committees. "More than half of China's villages have not yet established independent rural collective economic organizations." (Guan, 2020) This is an issue left over from history in a specific period. The 1983 Notice on the "Separation of Political and Social Organizations and the Establishment of Township Governments" is a practice of supporting rural collective economic organizations and villagers' committees in implementing a set of two bodies. Up to now, when the conditions for "separation of political and social sectors" have gradually matured, the form of "semi-separation of political and social sectors" still exists in many places, with overlapping staff among institutions, such as Meitan County in Guizhou Province (Xia, 2018). "Two brands, a set of team" approach fundamentally did not achieve "political and economic separation", the crossover of personnel easily lead to the confusion of two independent legal person, not conducive to the realization of "political and economic separation". 
Third, the economic functions of rural collective economic organizations are not independent. Many rural collective economic organizations have not yet got rid of the interference of the grassroots political power, resulting in their economic and financial control is not independent, the most typical phenomenon is the "village account township management" phenomenon. For example, the "Interim Measures for the Financial Management of Rural Collective Economic Organizations in Dongkou County" stipulates that special administrative organs established by township governments are responsible for the unified accounting and escrow of the financial accounts of village collective economic organizations. This obviously violates the legal person principle of rural collective economic organization and weakens the financial autonomy of rural collective economic organization. Since rural collective economic organizations have independent civil subject status in legislation, it means that rural collective economic organizations have the qualification of independent management of their own property. However, "village account and township management" negates its economic main body status in practice and hinders the process of market main body of collective economic organization.

\section{The Consummation Path That Rural Collective Economy Organizes Legal Person to Manage}

\subsection{The Charter Emphasizes Both Procedure and Entity}

1) Clarifying the procedure content of the articles of association in the form of a special chapter. First, under the guidance of the "Model Charter for Rural Collective Economic Organizations (Trial)" issued by the Ministry of Agriculture and Rural Affairs of the People's Republic of China, the procedures for the formulation and amendment of the charter shall be prescribed as an independent special chapter, and the conditions, time limit, voting rules and meeting minutes system for the amendment of the charter shall also be stipulated. For each amendment of the articles of association, a complete meeting record shall be prepared for verification. Meanwhile, the whole amendment process shall be supervised by the supervisory body to ensure that the conditions, time limit and voting rules for the amendment of the Articles of Association are in accordance with the provisions of the Articles of Association. The articles of association amended in the absence of any of the conditions shall be deemed invalid and shall have no effect on the shareholders. Second, to ensure the openness of the articles of association, in the articles of association clearly stated that the articles of association to open as effective requirements. Specifically, information bulletin boards and network equipment of rural collective economic organizations can be publicized to ensure collective members and the public can know and inquire.

2) Use "general" plus "special" to improve the substantive content of the Articles of Association. On the macro level, the contents of the articles of association shall be stipulated with reference to the "Model Articles of Association of 
Rural Collective Economic Organizations (trial)" printed and issued by the Ministry of Agriculture and Rural Affairs of the People's Republic of China. The main contents of the articles of association shall include the legal person's name, residence, property, name of members, term of office and power of legal representative, generation and operation of governance structure, membership and loss of members, rights and obligations of members, distribution principle of interests and property status of rural collective economic organizations; On the micro level, the contents of the constitution of rural collective economic organization should be built around its particularity. Articles of association of the content is not only to highlight the rural collective economic organization's special legal status, indicate the vote and equality, show that members of the distribution of benefits free sex identity of shareholders and members are strictly prohibited to outside equity transfer and clarify the economic main body status of the rural collective economic organizations, but also according to the actual circumstance of the rural collective economic organizations of different design endowment, poverty alleviation and shares of equity ratio.

\subsection{The Governance Structure Emphasizes the Combination of Internal and External Supervision}

First, unify the governance structure mode. First of all, the construction of the governance structure should adopt the "three-tier" governance model of authority-executive agency-supervision agency. In the governance structure, there is no lack of supervision institutions. The absence of supervision institutions will lead to the lack of supervision of the power institutions and executive institutions in the exercise of power, which will easily lead to the abuse of power. It is necessary to adhere to the special nature of rural collective economic organization when constructing the specific governance structure, but this does not mean that the "three-tier" governance structure of corporate style cannot be used for reference. The special characteristics of rural collective economic organizations can be reflected through the selection of personnel in the governance structure. For example, the selection procedures of personnel in the governance structure shall be reasonably guided by the people's government at a higher level, and the members of the governance structure shall be guaranteed to be members of the collective. Moreover, the "three-tier" governance structure model has been tested by the company and proved that it can ensure the normal operation of the company, while the rural collective economic organization and the company are both economic organizations in nature and have certain similarities. Secondly, the responsibilities and composition rules between the governance structures should be clarified to achieve the effect of checks and balances. A good institutional design is the basis for the normal operation of legal persons. In order to make the internal structure of governance reach the level of checks and balances, power separation is the most appropriate way to choose. In terms of personnel composition, the personnel of the supervisory and executing agencies must not be confused; In terms of functions and duties, the power of the authority must 
be clearly defined, and the exercise of the supervisory power by the supervisory authority must be implemented. It insists that the executing agency must exercise specific management and execution functions under the supervision of the supervising agency, and at the same time entrusts the executing agency with the right to review the objections to the supervising agency, so as to achieve the balance of power.

Second, pay attention to external supervision of the governance structure. Many local normative documents generally attach importance to the supervision of administrative organs on the operation and management of rural collective economic organizations, but generally ignore the supervision role of specialized intermediary agencies. At present, the local rural collective economic organizations generally set up supervision institutions, and it is clear that the management of collective assets shall be managed by the executing agency, and the specific management behaviors shall be supervised by the supervision agency. But only relying on internal supervision is not enough, because of the closed nature of rural collective economic organizations, it is easy to lead to the problem that a few people control collective assets. It is important to emphasize the external supervision of administrative organs, but the supervision and guidance of people's governments at all levels are in principle and cannot interfere with the normal operation of rural collective economic organizations. In particular, rural collective economic organizations are required to have special accounting accounts to ensure that the collective property is not harmed. Due to the concern for the collective's own rights and interests, and the professional formulation of accounting accounts, it is easy for collective assets to be controlled by a few people only relying on internal supervision. Accounting firms are both professional and supervisory, and their involvement is conducive to the guidance and external supervision of the financial situation, so as to form a reasonable situation of internal and external supervision. After verification by the accounting firm, the results shall be publicized to all shareholders to ensure that shareholders' right to know will not be infringed.

\section{3. "Separation of Government and Economy" at Different Levels}

The situation of "no division of government and economy" focuses on reflecting the public service function of rural collective economic organizations, which is not conducive to the realization of the market status of rural collective economic organizations. To achieve the goal of separating politics from economy, it is necessary to clarify the relationship and functions between collective economic organizations and other grass-roots organizations, and fully reflect the economic functions of rural collective economic organizations. Therefore, we should take the initiative to create opportunities and separate the administrative functions and economic functions of grassroots organizations (Fang, 2018).

First, clarify the boundary with the villagers committee. Specifically, it is necessary to define the functions of collective economic organizations and villagers' committees, and gradually remove the economic functions of villagers' 
committees in the operation and management of collective assets. The collective economic organization and the villagers committee are two different legal persons, whose functions are also different, and their functional boundaries should be clarified. The villagers committee is a non-profit-making legal person in a special legal person with certain administrative color in nature (Li, 2017), and its scope of engaging in civil activities is limited. The function of the mass autonomous legal person is to perform public services, while the function of the rural collective economic organization is more reflected in the aspect of engaging in economic activities, transforming the collective land into real assets. Even though the "Organic Law of the Villagers' Committees" states that the villagers' committees have the right to manage collectively owned land according to law, collective land includes land for public welfare purposes as well as land for commercial purposes. Therefore, the economic function and public service function can be defined according to the different USES of land, and the economic function of the villagers committee on collective assets can be separated. First, in places where rural collective economic organizations are established, the land for public welfare purposes should be managed by villagers' committees, so as to realize their public service functions. Second, land for profit-making purposes should be turned over to rural collective economic organizations for operation and management. In particular, economic functions can be realized by building workshops, taking land as a factor of production to become a shareholder and inviting public bidding, so as to further clarify the boundary of villagers' committees' economic functions over collective land.

Second, solve the problem of overlapping personnel. Specifically, to ensure the separation of the staff of the rural collective economic organization and the villagers' committee, all local regulations explicitly prohibit the issue of overlapping staff between the board of directors and the board of supervisors, but generally ignore the issue of overlapping staff between the rural collective economic organization and the villagers' committee. The form of organization of villagers committee and rural collective economic organization is different, the former has more administrative color, while the latter represents economic organization. The overlapping of personnel between them and the practice of implementing a set of team is more inclined to "the integration of politics and economy". For the realization of "political and economic separation", the constitution should clearly stipulate that the management structure of the rural collective economic organization and the villagers' committee shall not overlap in personnel, and establish the personnel selection mechanism independent of the villagers' committee, so as to realize the separation situation of "two brands, two groups of people”.

Third, clarifying the economic subject status of rural collective economic organizations. It is necessary to make clear the essential attribute of rural collective economic organization (Guan, 2018). In the aspect of property supervision, an independent asset supervision system should be established, which shall be su- 
pervised by the supervision institutions in the governance structure, supplemented by the verification of accounting institutions, so as to eliminate the appearance of "village account and township management". Grassroots political power should not escrow the property of collective economic organizations, its guidance and supervision should be in principle supervision. Specifically, it provides guidance for the formulation of the constitution of the collective economic organization, supervises the macro-operation status of the rural collective economic organization, and provides market information for its economic activities, but should not affect the status of the market subject of the rural collective economic organization.

\section{Conclusion}

Regions are paying more and more attention to the exploration of the governance of rural collective economic organizations. It is only limited by the different levels of development in various regions of our country and the lack of national legislation for rural collective economic organizations, which has led to various regions. There are certain flaws in the regulations, which undoubtedly puts a severe test on the governance of rural collective economic organizations. Therefore, it is necessary to grasp the special nature of collective economic organizations, and put the special nature into the constitution and governance structure of rural collective economic organizations, so as to distinguish rural collective economic organizations from other legal persons and villagers' committees, and then realize the independent legal person status of rural collective economic organizations.

\section{Conflicts of Interest}

The author declares no conflicts of interest regarding the publication of this paper.

\section{References}

Fang, Z. Q. (2018). Special Legal Person of Rural Collective Economic Organization: Theoretical Research and Practical Exploration. The Scientific Development, No. 1, 94-105.

Guan, H. Y. (2018). The Realistic Foundation and Future Way of Legislation of Rural Collective Economic Organization Legal Person. Journal of Gansu University of Political Science and Law, No. 1, 34-46.

Guan, H. Y. (2019). The Basic Idea of Legislative Construction of Legal Person Governance Mechanism of Rural Collective Economic Organization. Journal of Suzhou University (Philosophy and Social Sciences Edition), No. 1, 51-60.

Guan, H. Y., \& Fu, C. C. (2020). Alienation and Rectification of Democratic Decision-Making of Rural Collective Economic Organization Legal Person. Seeking Truth, No. 3, 84-94.

Guo, J. (2019). On the Status of Profit-Making Legal Person and Legislative Path of Rural Collective Economic Organization. The Contemporary Law, No. 5, 79-88.

Jiao, F. M. (2019). Research on Rural Collective Economic Organization System from the 
perspective of General Principles of Civil Law. Jianghai Journal, No. 5, 240-246.

Li, Y. J. (2017). The Historical Vicissitudes and Legal Structure of Collective Economic Organization Legal Person. Comparative Study, No. 4, 35-52.

Li, Z. J. (2019). Analysis on the Standardized Path of New Rural Collective Economic Organization Charter. Rural Economy and Technology, No. 6, 17-18.

Qu, M. H. (2018). Research on the Legal Person System of Rural Collective Economic Organizations. Political Law Forum, No. 2, 28-40.

Xia, Y. (2018). China's Rural Collective Property Rights System Reform Pilot: Practice, Effectiveness and Promotion Countermeasures. Agricultural Economics, No. 4, 36-42.

Zhang, X. S. (2016). Rural Grassroots Governance Structure: Current Situation, Problems and Prospects. Search, No. 7, 4-11.

Zhao, X. L. (2018). The Legal Nature and Effectiveness of the Constitution of Rural Collective Economic Organization Are Affirmed. Agricultural Economics, No. 7, 57-69. 